\title{
The case for an elderly targeted stroke management
}

\section{Osvaldo Fustinoni *}

Department of Neurology, INEBA-Instituto de Neurociencias Buenos Aires, Facultad de Medicina, Universidad de Buenos Aires, Buenos Aires, Argentina

\section{Edited by:}

Ashfaq Shuaib, University of Alberta,

Canada

\section{Reviewed by:}

Ashfaq Shuaib, University of Alberta,

Canada

Hidetoshi Kasuya, Tokyo Women's

Medical University, Japan

\section{*Correspondence.}

Osvaldo Fustinoni, Department of

Neurology, INEBA-Instituto de

Neurociencias Buenos Aires, Facultad

de Medicina, Universidad de Buenos

Aires, Guardia Vieja 4435, C1192 AAW

Buenos Aires, Argentina.

e-mail:fusti@fibertel.com.ar
Stroke is a leading cause of death and disability worldwide. The elderly, in whom atrial fibrillation (AF) is most prevalent, carry the greatest risk, undergoing more recurrent, deadlier strokes, with bigger deficits, slower recoveries, and more comorbidities. Evidence-based data on advanced age stroke management are scarce. Age-related cerebral changes might undermine the benefit of established stroke treatments. Nevertheless, the elderly should probably also undergo thrombolysis for ischemic stroke: they do not bleed more, and die not because of hemorrhage but of concomitant illnesses. Beyond natural bleeding risks, AF in advanced age has a high embolic potential if not anticoagulated. Standard or lower intensity warfarin anticoagulation prevents embolic stroke in the elderly with a hemorrhage risk even lower than aspirin. In fact, adverse effects seem to occur more often with aspirin. Excess anticoagulation hazards are prevented with lower starting doses, stricter corrections, more frequent International Normalized Ratio monitoring, and longer adjustment intervals. Validated prognostic scores such as $\mathrm{CHADS}_{2}$ help minimize bleeds. Direct inhibitors have recently shown a benefit similar to warfarin with fewer hemorrhages. Carefully tailoring antithrombotics to this age group is therefore useful. Antihypertensives probably help 80plus stroke patients as well, but the risk/benefit of lowering blood pressure in secondary stroke prevention at that age is uncertain. Evidence-based data on diabetes management and use of lipid-lowering drugs are still lacking in this age group. In summary, emerging data suggest that stroke management should be specifically targeted to the elderly to better prevent its devastating consequences in the population at the highest risk.

\section{Keywords: stroke management, elderly population, antithrombotics}

\section{THE CASE FOR AN ELDERLY TARGETED STROKE MANAGEMENT}

Stroke is one of the leading causes of death and the main cause of disability worldwide. The stroke rate increases with age: beyond 55 , it doubles each successive decade, and by 2050 the 65-plus world population will outnumber the rest (Wolf et al., 1992; Brown et al., 1996; Chen et al., 2010). The elderly are therefore at greater cerebrovascular risk than anyone, and stroke will probably acquire epidemiological proportions in the near future.

Thrombolysis, anticoagulation, antihypertensive, antiplatelet, and antilipemic agents have all been proven of benefit in stroke treatment and prevention in the population at large. However, management strategies useful in younger adults may not be equally effective in the elderly, who undergo age-related cerebral changes that might undermine that benefit, or entail further clinical risk.

Brain weight decreases $0.1-0.2 \%$ yearly between the ages of 20 and 50 , and $0.3-0.5 \%$ yearly beyond 70 (Anderson et al., 1983; Pfefferbaum et al., 1994). Leukoaraiosis, a patchy or confluent subcortical/periventricular hypointensity on CT (or high signal intensity on MRI), occurs in up to one-third of people aged 6584 , and in up to $44 \%$ of patients with stroke and transient ischemic attack (TIA). It predicts gait disturbances and cognitive decline in the very elderly, and its degree correlates with the risk of recurrent stroke (Breteler et al., 1994; Pfefferbaum et al., 1994; de Groot et al., 2000; Debette et al., 2007; Smith, 2010). With aging, blood brain barrier permeability and plasma albumin ratio in the cerebrospinal fluid increase. Capillaries enlarge, elongate, and disrupt perfusion. Cerebral blood flow reductions diminish protein synthesis, induce changes in intracellular $\mathrm{pH}$ and water content, cause glutamate/lactate accumulation, impair ATP synthesis, decrease neuron excitability, and bring on electrolyte imbalance and ultimately ischemic neuronal death (Farrall and Wardlaw, 2009).

In various "very old" populations (beyond 80 years of age), stroke predominates in women (Rojas et al., 2007; Andersen et al., 2010). Atrial fibrillation (AF) is most prevalent in the elderly, with up to $23.5 \%$ of associated stroke risk at $80-89$ years (Wolf et al., 1991; Fuster et al., 2001; Adams et al., 2008), and the highest hazard ratio beyond 65 (Rodgers et al., 2004). Contrary to younger populations, hypertension and hyperlipidemia are less significant risk factors in the very old (Weverling-Rijnsburger et al., 2003; Rodgers et al., 2004; Milionis et al., 2005; Babatsikou and Zavatsanou, 2010).

Stroke in patients beyond 85 is deadlier, entails longer hospital stays, and results in bigger deficits and slower recoveries that require assistance in daily living and ultimately institutionalization (Arboix et al., 2000). Older stroke patients have a substantially higher risk of stroke recurrence (Johnston et al., 2000; Kaplan et al., 2005), and comorbidities that increase disability (Hickenbottom et al., 2002).

Old age is therefore associated with specific cerebral structural changes, risk factors, and clinical features that may all impair 
or delay stroke recovery. Unfortunately, because very few old patients were included in the large stroke clinical trials, reliable data on elderly stroke management are scarce and have only recently started to emerge. As a result, the population most in need of clear stroke treatment recommendations has been neglected.

\section{INTRAVENOUS THROMBOLYSIS}

Intravenous thrombolysis with rt-PA reduces stroke disability. However, breakthrough trials demonstrating this benefit have either excluded very elderly patients, or randomized very few (The National Institute of Neurological Disorders, 1995; Hacke et al., 2008). These restrictions do not seem warranted, since patients over 80 have not shown a higher bleeding risk, both in small cohort studies and in larger databases (Tanne et al., 2000; Berrouschot et al., 2005; Mouradian et al., 2005; Engelter et al., 2006; Sylaja et al., 2006; Ford et al., 2010; Mishra et al., 2010; Table 1). This may depend on how bleeding is defined (The National Institute of Neurological Disorders, 1995; Wahlgren et al., 2007), but in any case, elderly stroke patients do not seem to die as a consequence of hemorrhage or thrombolysis, but of concomitant illnesses (Schwark and Schellinge, 2006; Alshekhlee et al., 2010). So, if the ultimate goal is to reduce death and disability, present data suggest the elderly should undergo thrombolysis under the same criteria as the general population.

\section{ATRIAL FIBRILLATION, ANTICOAGULATION, AND ANTIPLATELET THERAPY}

Atrial fibrillation leads to left atrial thrombi, carries a sixfold annual stroke risk (Wolf et al., 1991), and is most prevalent in the elderly. An estimated 5.6 million people will have it by 2050 in the USA, of which $50 \%$ will be over 80 (Go et al., 2001). Cardioembolic stroke due to AF is consequently a very high risk in this group. From several clinical trials we know that oral anticoagulation reduces relative stroke risk by about $68 \%$ and mortality by $33 \%$, and hence is the best means to prevent cardioembolic stroke in the general population (Lip and Lowe, 1996). However, old patients, anticoagulated or not, may also be at high bleeding risk, due to factors such as amyloid angiopathy (Rosand et al.,

Table 1 | Thrombolysis in general and advanced age populations.

\begin{tabular}{lll}
\hline & General population & $\begin{array}{l}\text { Advanced age } \\
\text { population }\end{array}$ \\
\hline THROMBOLYSIS & & \\
$\begin{array}{l}\text { Symptomatic ICH } \\
\text { (\%) }\end{array}$ & $\begin{array}{l}\text { Neurological Disorders, 1995), } \\
\text { (The National Institute of }\end{array}$ & 3 (Tanne et al., 2000), \\
& $\begin{array}{l}\text { 2.4 (Hacke et al., 2008), } 6 \\
\text { (Tanne et al., 2000), 2.6 }\end{array}$ & \\
& (Berrouschot et al., 2005) & \\
& OR 1.6 (95\% Cl 1.5-1.7) (Ford & 1.4 (95\% Cl 1.3-1.6) \\
Outcome (modified \\
ranking scale) & et al., 2010) & (Ford et al., 2010)
\end{tabular}

Symptomatic intracerebral hemorrhage (ICH) and outcome (The National Institute of Neurological Disorders, 1995; Tanne et al., 2000; Berrouschot et al., 2005; Hacke et al., 2008; Ford et al., 2010).
2000), ischemia of arterial (rather than cardioembolic) mechanism and concomitant medication (Gorter, 1999), or brain microbleeds (Roob et al., 1999). Those with AF may in fact have both the highest spontaneous ischemic stroke risk and, when anticoagulated, the highest bleeding risk (Warfarin versus aspirin, 1994).

Prescribing anticoagulation is therefore a critical challenge in the elderly (Hylek et al., 2006). Beyond conventional contraindications, such as stomach ulcer, physicians often avoid anticoagulation in elderly patients, for fear of intracerebral hemorrhage, falls, and faulty compliance (with or without cognitive decline), choosing to leave the patient at higher embolic risk as a result (Lew and Lim, 2002; van Walraven et al., 2009). Nevertheless, using conventional optimal anticoagulation intensity (International normalized ratio, INR 2.0-3.0; The European Atrial Fibrillation Trial Study Group, 1995; Hylek et al., 1996; Stroke prevention in atrial fibrillation III, 1996), one trial has shown the benefit of warfarin over aspirin in preventing embolic stroke in the elderly, with a $46 \%$ relative risk reduction, and low major extracranial hemorrhage rates, not significantly different from those with aspirin: 1.4 vs. $1.6 \%$ per year (Mant et al., 2007). With the same standard anticoagulation intensity, a smaller trial looked at specific adverse events (death, thromboembolism, severe hemorrhage, withdrawal from the study), which turned out to be very significantly more frequent with aspirin (33\%) than with warfarin: $6 \%$, $p=0.002$ (Rash et al., 2007; Table 2). These are sobering results, as antiplatelet agents are not felt to be dangerous and usually prescribed quite freely in the elderly, on the basis of general population trials.

Excess anticoagulation and INR variability seem to be, more than anything, the main risk factors for bleeding in all patients (Ansell et al., 2008). These may be prevented in the elderly with a lower warfarin starting dose ( $4 \mathrm{mg}$ ), more frequent INR monitoring (with a maximum interval of 3 weeks), longer intervals between two dose adjustments (at least 4 days apart, especially with higher doses), and, if necessary, stricter or even $1 \mathrm{mg}$ step dose adjustments, as shown in computer-assisted warfarin management systems (Harrison et al., 1997; Gage et al., 2000; Ansell et al., 2008; Gouin-Thibault et al., 2010). The American Geriatrics Society recommends daily INR testing until stable, followed by two to three times/week testing for 1-2 weeks, weekly testing for 1 month, and monthly testing thereafter (American Geriatrics Society Clinical Practice Committee, 2002). Lower intensity anticoagulation regimens, which have included the elderly, with target INRs $<2$, can provide the same prevention efficacy than standard intensity treatments, with significantly lower bleeding risk (Yamaguchi, 2000; Pengo et al., 2010).

Table 2 | Anticoagulation (warfarin) vs. antiplatelet therapy (aspirin) for stroke prevention in atrial fibrillation in the elderly ${ }^{49,50}$.

\begin{tabular}{|c|c|c|}
\hline & Warfarin (INR 2.0-3.0) & Aspirin \\
\hline $\begin{array}{l}\text { Major extracranial } \\
\text { hemorrhage (\%) }\end{array}$ & 1.4/year (Mant et al., 2007) & $\begin{array}{l}\text { 1.6/year (Mant et al., } \\
\text { 2007) }\end{array}$ \\
\hline Adverse events (\%) & 6 (Rash et al., 2007) & 33 (Rash et al., 2007) \\
\hline
\end{tabular}


Dabigatran etexilate, approved by the FDA in October 2010 for stroke prevention in AF, inhibits coagulation by specifically and reversibly binding thrombin (Hussar and Zimmerman, 2011). At a dose of $110 \mathrm{mg}$ twice daily, it showed similar embolic stroke and systemic embolism rates (non-inferior $p<0.001$ ), but significantly lower major bleeding rates than warfarin in a large trial (Connolly et al., 2009). However, in patients $\geq 75$ years, intracranial bleeding risk was lower but extracranial bleeding risk was similar or higher with dabigatran (Eikelboom et al., 2011). Apixaban, a novel oral direct factor Xa inhibitor, at a dose of $5 \mathrm{mg}$ twice daily compared to warfarin (at a target INR of 2.0-3.0), was superior in preventing stroke or systemic embolism $(p<0.001$ for non-inferiority, $p=0.01$ for superiority), caused less bleeding $(p<0.001)$, and resulted in lower mortality $(p=0.047)$, in a study of 18201 patients with a mean age of 70 years, of which $>31 \%$ were at least 75, a welcome older stroke risk population trial (Granger et al., 2011). Rivaroxaban, another oral factor Xa inhibitor, was approved by the FDA in November 2011. At a daily dose of $20 \mathrm{mg}$, vs. dose-adjusted warfarin, it was non-inferior to warfarin for the prevention of stroke or systemic embolism $(p<0.001)$, and showed less intracranial and fatal bleeding $(p=0.003)$, but no difference in the risk of major bleeding (Patel et al., 2011), in a population of patients with a mean age of 73 years. While with these newer direct inhibitors we may be at the brink of a breakthrough allowing us, at long last, to forget about INRs, it is still uncertain whether these agents will truly result in a lower hemorrhagic risk in everyday practice. Other compounds are under investigation.

Finally, validated risk stratification schemes for better decisionmaking are other useful tools to minimize bleeding risk. For instance, the validated $\mathrm{CHADS}_{2}$ score allocates points to the presence of five clinical risk factors: congestive heart failure, hypertension, age $>75$ years, diabetes mellitus ( 1 point each), and prior stroke/TIA (2 points; Gage et al., 2001). For patients with a $\mathrm{CHADS}_{2}$ score of 0 (annual stroke risk 1\%), the absolute benefit of warfarin is not substantially greater than that of aspirin. For patients with a $\mathrm{CHADS}_{2}$ score of 2 or more (annual stroke risk 4\%), warfarin is both beneficial and cost-effective. Patients with a $\mathrm{CHADS}_{2}$ score of 1 may have a choice of either, but most AF patients over 75 have a $\mathrm{CHADS}_{2}$ score of 2 or higher, and are therefore appropriate candidates for warfarin (Gage et al., 2004).

The HAS-BLED score (uncontrolled Hypertension, Abnormal renal/liver function, Stroke, Bleeding history or predisposition, Labile INR, Elderly over 65 years, concomitant Drugs/alcohol) targets AF patients under anticoagulation. One point is given for each risk factor, with a maximum of 9 . A score of 3 or more suggests high risk bleeding (Lip et al., 2011).

It is clear that to avoid both embolic stroke and bleeding risk in elderly AF patients, the choice of antithrombotic drug, dosage, treatment regimen, and appropriate evaluation of cost/benefit should be carefully tailored to the specific characteristics of this age group.

\section{HYPERTENSION AND ANTIHYPERTENSIVE TREATMENT}

Arterial hypertension is recognized as one of the most prevalent modifiable stroke risk factors. Several trials have shown the benefit of antihypertensive drugs for primary and secondary stroke prevention in the general population. Some of these trials or meta analyses have shown similar results in primary prevention in the elderly (Gueyffier et al., 1999; Beckett et al., 2008), but there are not enough data on secondary stroke prevention. In one of the elderly targeted trials of hypertension treatment, only $7 \%$ of participants had a history of previous stroke (Gueyffier et al., 1999). The heart outcomes prevention evaluation (HOPE) trial included about $11 \%$ stroke survivors, but patients beyond 80 were excluded (Bosch et al., 2002). In the study on cognition and prognosis in the elderly (SCOPE), a trial involving almost 5000 elderly patients, only $4 \%$ had had a prior stroke (Lithell et al., 2003). Secondary prevention stroke trials, such as PROGRESS, PATS, and MOSES were not specifically addressed to the elderly, and the mean age of the populations studied was $<70$ (PATS Collaborating Group, 1995; PROGRESS Collaborative Group, 2001; Schrader et al., 2005). Antihypertensives would probably benefit 80-plus stroke patients as well, but aren't there any risks in lowering the blood pressure in the elderly? Is not cerebral blood flow compromised as a consequence? In one meta analysis addressing antihypertensives in old people, no treatment benefit was seen for cardiovascular death, and there was a non-significant $6 \%$ relative excess death from all causes (Gage et al., 2004). How can this be explained? Shouldn't such a result be investigated further?

\section{DIABETES, CHOLESTEROL, AND LIPID-LOWERING TREATMENTS}

Although diabetes is considered a stroke risk factor in the elderly, intensive $\mathrm{HbA}_{1 \mathrm{c}}$-lowering treatment $(<6.5 \%)$ has been discouraged by the American Heart - American Stroke Association guidelines because of the higher death risks involved, a recommendation issued on the basis of data obtained from general and not from advanced age populations (Action to Control Cardiovascular Risk in Diabetes Study Group et al., 2008; Furie et al., 2011).

Epidemiological studies demonstrate a relationship between high cholesterol and vascular disease in the elderly (Prospective Studies Collaboration, 2007), and the benefit of statins in preventing vascular disease and stroke, despite the lack of association of cholesterol levels with ischemic stroke risk (Cholesterol Treatment Triallists' Collaboration, 2005). Again most of the evidence on statin efficacy in primary and secondary stroke prevention comes from subgroup analyses from general population trials, despite a large study reporting a $25 \%$ relative risk reduction in secondary stroke (Afilalo et al., 2008). There is only one secondary prevention trial with stroke as a primary end-point, but with very few patients over 80 (The Stroke Prevention by Aggressive Reduction in Cholesterol Levels Investigators, 2006). So even when the available evidence supports statins as effective in primary and secondary vascular prevention in the very old, the data are just not enough to make evidence-based decisions in stroke patients.

In summary, present available evidence shows that some stroke management schemes may reasonably be applied to the elderly as safely as to the population at large, but not others. Emerging data suggest that, because the risk/benefit ratio is still uncertain, stroke management in old patients should be addressed separately. Better evidence could help the elderly, the population at highest stroke risk, prevent the devastating consequences of stroke. 


\section{REFERENCES}

Action to Control Cardiovascular Risk in Diabetes Study Group, Gerstein, H. C., Miller, M. E., Byington, R. P., Goff, D. C. Jr., Bigger, J. T., Buse, J. B., Cushman, W. C., Genuth, S., Ismail-Beigi, F., Grimm, R. H. Jr., Probstfield, J. L., Simons-Morton, D. G., and Friedewald, W. T. (2008). Effects of intensive glucose lowering in type 2 diabetes. N. Engl. J. Med. 358, 2545-2459.

Adams, R. J., Albers, G., Alberts, M. J., Benavente, O., Furie, K., Goldstein, L. B., Gorelick, P., Halperin, J., Harbaugh, R., Johnston, S. C., Katzan, I., Kelly-Hayes, M., Kenton, E. J., Marks, M., Sacco, R. L., Schwamm, L. H., American Heart Association, and American Stroke Association. (2008). Update to the AHA/ASA recommendations for the prevention of stroke in patients with stroke and transient ischemic attack. Stroke 39, 1647-1652. [Erratum in: Stroke 2010; 41, e455].

Afilalo, J., Duque, G., Steele, R., Jukema, J. W., de Craen, A. J. M., and Eisenbert, M. J. (2008). Statins for secondary prevention in elderly patients. J. Am. Coll. Cardiol. 51, 37-45.

Alshekhlee, A., Mohammadi, A., Mehta, S., Edgell, R. C., Vora, N., Feen, E., Kale, S., Shakir, Z. A., and CruzFlores, S. (2010). Is thrombolysis safe in the elderly?: analysis of a national database. Stroke 41, 2259-2264.

American Geriatrics Society Clinical Practice Committee. (2002). The use of oral anticoagulants (warfarin) in older people. American geriatrics society guideline. J. Am. Geriatr. Soc. 50, 1439-1445.

Andersen, K. K., Andersen, Z. J., and Olsen, T. S. (2010). Age and gender specific prevalence of cardiovascular risk factors in 40102 patients with first ever ischemic stroke. A Nationwide Danish Study. Stroke 41, 2768-2774.

Anderson, J. M., Hubbard, B. M., Coghill, G. R., and Slidders, W. (1983). The effect of advanced old age on the neuron content of the cerebral cortex. Observations with an automatic image analyzer point counting method. J. Neurol. Sci. 58, 235-246.

Ansell, J., Hirsh, J., Hylek, E., Jacobson, A., Crowther, M., Palareti, G., and American College of Chest Physicians. (2008). Pharmacology and management of the vitamin K antagonists: American college of chest physicians evidence-based clinical practice guidelines (8th Edition). Chest 133, s160-s198.
Arboix, A., García-Eroles, L., Massons, J., Oliveres, M., and Targa, C. (2000). Acute stroke in very old people: clinical features and predictors of inhospital mortality. J. Am. Geriatr. Soc. 48, 36-41.

Babatsikou, F., and Zavatsanou, A. (2010). Epidemiology of hypertension in the elderly. Health Sci. J. 4, 24-30.

Beckett, N. S., Peters, R., Fletcher, A. E., Staessen, J. A., Liu, L., Dumitrascu, D., Stoyanovsky, V., Antikainen, R. L., Nikitin, Y., Anderson, C., Belhani, A., Forette, F., Rajkumar, C., Thijs, L., Banya, W., Bulpitt, C. J., and HYVET Study Group. (2008). Treatment of hypertension in patients 80 years of age or older. N. Engl. J. Med. 358, 1887-1898.

Berrouschot, J., Rother, J., Glahn, J., Kucinski, T., Fiehler, J., and Thomalla, G. (2005). Outcome and severe hemorrhagic complications of intravenous thrombolysis with tissue plasminogen activator in very old ( $>$ or $=80$ years) stroke patients. Stroke 36, 2421-2425.

Bosch, J., Yusuf, S., Pogue, J., Sleight, P., Lonn, E., Rangoonwala, B., Davies, R., Ostergren, J., Probstfield, J., and HOPE Investigators. (2002). Heart outcomes prevention evaluation. Use of ramipril in preventing stroke: double blind randomized trial. BMJ 324, 699-702.

Breteler, M. M., Swieten, J. C., Bots, M. L., Grobbee, D. E., Claus, J. J., van den Hout, J. H., van Harskamp, F., Tanghe, H. L., de Jong, P. T., and van Gijn, J. (1994). Cerebral white matter lesions, vascular risk factors, and cognitive function in a populationbased study: the Rotterdam study. Neurology 44, 1246-1252.

Brown, R. D., Whisnant, J. P., Sicks, J. D., O'Fallon, W. M., and Wiebers, D. O. (1996). Stroke incidence, prevalence, and survival: secular trends in Rochester, Minnesota, through 1989. Stroke 27, 373-380.

Chen, R. L., Balami, J. S., Esiri, M. M., Chen, L. K., and Buchan, A. M. (2010). Ischemic stroke in the elderly: an overview of evidence. Nat. Rev. Neurol. 6, 256-265.

Cholesterol Treatment Triallists' Collaboration. (2005). Efficacy and safety of cholesterol -lowering treatment: prospective meta-analysis of data from 90056 participants in 14 randomized trials on statins. Lancet 366, 1267-1278.

Connolly, S. J., Ezekowitz, M. D., Yusuf, S., Eikelboom, J., Oldgren, J., Parekh, A., Pogue, J., Reilly, P. A., Themeles, E., Varrone, J., Wang, S., Alings, M.,
Xavier, D., Zhu, J., Diaz, R., Lewis, B. S., Darius, H., Diener, H. C., Joyner, C. D., Wallentin, L., RE-LY Steering Committee and Investigators. (2009). Dabigatran versus warfarin in patients with atrial fibrillation. $N$. Engl. J. Med. 361, 1139-1151.

de Groot, J. C., de Leeuw, F. E., Oudkerk, M., van Gijn, J., Hofman, A., Jolles, J., and Breteler, M. M. (2000). Cerebral white matter lesions and cognitive function: the Rotterdam Scan Study. Ann. Neurol. 47, 145-151.

Debette, S., Bombois, S., Bruandet, A., Delbeuck, X., Lepoittevin, S., Delmaire, C., Leys, D., and Pasquier, F. (2007). Subcortical hyperintensities are associated with cognitive decline in patients with mild cognitive impairment. Stroke 38, 2924-2930.

Eikelboom, J. W., Wallentin, L., Connolly, S. J., Ezekowitz, M., Healey, J. S., Oldgren, J., Yang, S., Alings, M., Kaatz, S., Hohnloser, S. H., Diener, H. C., Franzosi, M. G., Huber, K., Reilly, P., Varrone, J., and Yusuf, S. (2011). Risk of bleeding with 2 doses of dabigatran compared with warfarin in older and younger patients with atrial fibrillation: an analysis of the randomized evaluation of longterm anticoagulant therapy (RE-LY) trial. Circulation 123, 2363-2372.

Engelter, S. T., Bonati, L. H., and Lyrer, P. A. (2006). Intravenous thrombolysis in stroke patients of $>$ or $=80$ versus $<80$ years of age - a systematic review across cohort studies. Age Ageing 35, 572-580.

Farrall, A. J., and Wardlaw, J. M. (2009). Blood-brain barrier: ageing and microvascular disease- systematic review and meta-analysis. Neurobiol. Aging 30, 337-352.

Ford, G. A., Ahmed, N., Azevedo, E., Grond, M., Larrue, V., Lindsberg, P. J., Toni, D., and Wahlgren, N. (2010). Intravenous alteplase for stroke in those older than 80 years old. Stroke 41, 2568-2574.

Furie, K. L., Kasner, S. E., Adams, R. J., Albers GW; Bush, R. L., Fagan, S. C., Halperin, J. L., Johnston, S. C., Katzan, I., Kernan, W. N., Mitchell, P. H., Ovbiagele, B., Palesch, Y. Y., Sacco, R. L., Schwamm, L. H., Wassertheil-Smoller, S., Turan, T. N., and Wentworth, D. (2011). Guidelines for the prevention of stroke in patients with stroke or transient ischemic Attack. Stroke 42, 227-276.

Fuster, V., Rydén, L. E., Asinger, R. W., Cannom, D. S., Crijns, H. J., Frye, R. L., Halperin, J. L., KayGN, Klein, W. W., Lévy, S., McNamara, R. L., Prystowsky, E. N., Wann, L. S., Wyse,
D. G., Gibbons, R. J., Antman, E M., Alpert, J. S., Faxon, D. P., Fuster, V., Gregoratos, G., Hiratzka, L. F., Jacobs, A. K., Russell, R. O., Smith, S. C., Jr., Klein, W. W., AlonsoGarcia, A., Blomström-Lundqvist, C., de Backer, G., Flather, M., Hradec, J., Oto, A., Parkhomenko, A., Silber, S., and Torbicki, A. (2001). ACC/AHA/ESC guidelines for the management of patients with atrial fibrillation: executive summary a report of the American College of Cardiology/American Heart Association Task Force on practice guidelines and the european society of cardiology committee for practice guidelines and policy conferences (committee to develop guidelines for the management of patients with atrial fibrillation) developed in collaboration with the north american society of pacing and electrophysiology. Circulation 104, 2118-2150.

Gage, B. F., Fihn, S. D., and White, R. H. (2000). Management and dosing of warfarin therapy. Am. J. Med. 109, 481-488.

Gage, B. F., van Walraven, C., Pearce, L., Hart, R. G., Koudstaal, P. J., Boode, B. S., and Petersen, P. (2004). Selecting patients with atrial fibrillation for anticoagulation: stroke risk stratification in patients taking aspirin. Circulation 110, 2287-2292.

Gage, B. F., Waterman, A. D., Shannon, W., Boechler, M., Rich, M. W., and Radford, M. J. (2001). Validation of clinical classification schemes for predicting stroke: results from the National Registry of Atrial Fibrillation. JAMA 285, 2864-2870.

Go, A. S., Hylek, E. M., Philips, K. A., Chang, Y., Henault, L. E., Selby, J. V., and Singer, D. E. (2001). Prevalence of diagnosed atrial fibrillation in adults: national implications for rhythm management and stroke prevention: the Anticoagulation and Risk Factors in Atrial Fibrillation (ATRIA) Study. JAMA 285 , 2370-2375.

Gorter, J. W. (1999). Major bleeding during anticoagulation after cerebral ischemia: patterns and risk factors. Stroke prevention in reversible ischemia trial (SPIRIT). European Atrial Fibrillation Trial (EAFT) Study Groups. Neurology 53, 1319-1327.

Gouin-Thibault, I., Levy, C., Pautas, E., Cambus, J. P., Drouet, L., Mahé, I., Bal Dit Sollier, C., Horellou, M. H., Golmard, J. L., and Siguret, V. (2010). Improving anticoagulation control in hospitalized elderly patients on warfarin. J. Am. Geriatr. Soc. 58, 242-247. 
Granger, C. B., Alexander, J. H., McMurray, J. J. V., Lopes, R. D., Hylek, E. M., Hanna, M., Al-Khalidi, H. R., Ansell, J., Atar, D., Avezum, A., Bahit, M. C., Diaz, R., Easton, J. D., Ezekowitz, J. A., Flaker, G., Garcia, D., Geraldes, M., Gersh, B. J., Golitsyn, S., Goto, S., Hermosillo, A. G., Hohnloser, S. H., Horowitz, J., Mohan, P., Jansky, P., Lewis, B. S., Lopez-Sendon, J. L., Pais, P., Parkhomenko, A., Verheugt, F. W., Zhu, J., Wallentin, L., and ARISTOTLE Committees and Investigators. (2011). Apixaban versus warfarin in patients with atrial fibrillation. $N$. Engl. J. Med. 365, 981-992.

Gueyffier, F., Bulpitt, C., Boissel, J. P., Schron, E., Ekbom, T., Fagard, R., Casiglia, E., Kerlikowske, K., and Coope, J. (1999). Antihypertensive drugs in very old people: a subgroup meta-analysis of randomised controlled trials. INDANA Group. Lancet 353, 793-796.

Hacke, W., Kaste, M., Bluhmki, E., Brozman, M., Davalos, A., Guidetti, D., Larrue, V., Lees, K. R., Medeghri, Z., Machnig, T., Schneider, D., von Kummer, R., Wahlgren, N., Toni, D., and ECASS Investigators. (2008). Thrombolysis with alteplase 3 to 4.5 hours after acute ischemic stroke. N. Engl. J. Med. 359, 1317-1329.

Harrison, L., Johnston, M., Massicotte, M. P., Crowther, M., Moffat, K., and Hirsh, J. (1997). Comparison of 5-mg and 10-mg loading doses in initiation of warfarin therapy. Ann. Intern. Med. 126, 133-136.

Hickenbottom, S. L., Fendrick, A. M., Kutcher, J. S., Kabeto, M. U., Katz, S. J., and Langa, K. M. (2002). A national study of the quantity and cost of informal caregiving for the elderly with stroke. Neurology 58, 1754-1759.

Hussar, D. A., and Zimmerman, D. E. (2011). New drugs: dabigatran etexilate mesylate, fingolimod hydrochloride, and ulipristal acetate. J. Am. Pharm. Assoc. 51, 122-126.

Hylek, E. M., D’Antonio, J., EvansMolina, C., Shea, C., Henault, L. E., and Regan, S. (2006). Translating the results of randomized trials into clinical practice: the challenge of warfarin candidacy among hospitalized elderly patients with atrial fibrillation. Stroke 37, 1075-1080.

Hylek, E. M., Skates, S. J., Sheehan, M. A., and Singer, D. E. (1996). An analysis of the lowest effective intensity of prophylactic anticoagulation for patients with nonrheumatic atrial fibrillation. N. Engl. J. Med. 335, 540-546.
Johnston, S. C., Gress, D. R., Browner, W. S., and Sidney, S. (2000). Short-term prognosis after emergency diagnosis of TIA. JAMA 284, 2901-2906.

Kaplan, R. C., Tirschwell, D. L., Longstreth, W. T., and Manolio, T. A. (2005). Vascular events, mortality, and preventive therapy following ischemic stroke in the elderly. Neurology 65, 835-842.

Lew, S. J., and Lim, J. K. (2002). Stroke prevention in elderly patients with atrial fibrillation. Singapore Med. J. 43, 198-201.

Lip, G. Y., Frison, L., Halperin, J. L., and Lane, D. A. (2011). Comparative validation of a novel risk score for predicting bleeding risk in anticoagulated patients with atrial fibrillation the HASBLED (Hypertension, Abnormal Renal/Liver Function, Stroke, Bleeding History or Predisposition, Labile INR, Elderly, Drugs/Alcohol Concomitantly) score. J. Am. Coll. Cardiol. 57, 173-180.

Lip, G. Y., and Lowe, G. D. (1996). ABC of atrial fibrillation. Antithrombotic treatment for atrial fibrillation. BMJ 312, 45-49.

Lithell, H., Hansson, L., Skoog, I., Elmfeldt, D., Hofman, A., Olofsson, B., Trenkwalder, P., Zanchetti, A., and SCOPE Study Group. (2003). The Study on Cognition and Prognosis in the Elderly (SCOPE): principal results of a randomized doubleblind intervention trial. J. Hypertens. 21, 875-886.

Mant, J., Hobbs, F. D., Fletcher, K., Roalfe, A., Fitzmaurice, D., Lip, G. Y., and Murray, E., BAFTA investigators: Midland Research Practices Network. (2007). Warfarin versus aspirin for stroke prevention in an elderly community population with atrial fibrillation (the Birmingham atrial fibrillation treatment of the aged study, BAFTA): a randomised controlled trial. Lancet 370 , 493-503.

Milionis, H. J., Rizos, E., Goudevenos, J., Seferiadis, K., Mikhailidis, D. P., and Elisaf, M. S. (2005). Components of the metabolic syndrome and risk for first-ever acute ischemic nonembolic stroke in elderly subjects. Stroke 36, 1372-1376.

Mishra, N. K., Ahmed, N., Andersen, G., Egido, A., Lindsberg, P. J., Ringleb, P. A., Wahlgren, N. G., Lees, K. R., and VISTA and SITS collaborators. (2010). Thrombolysis in very elderly people: controlled comparison of SITS International stroke thrombolysis registry and virtual international stroke trials archive. BMJ 341, c6046.
Mouradian, M. S., Senthilselvan, A., Jickling, G., McCombe, J. A., Emery, D. J., Dean, N., and Shuaib, A. (2005). Intravenous rt- PA for acute stroke: comparing its effectiveness in younger and older patients. $J$. Neurol. Neurosurg. Psychiatr. 76, 1234-1237.

Patel, M. R., Mahaffey, K. W., Garg, J., Pan, G., Singer, D. E., Hacke, W., Breithardt, G., Halperin, J. L., Hankey, G. J., Piccini, J. P., Becker, R. C., Nessel, C. C., Paolini, J. F., Berkowitz, S. D., Fox, K. A., Califf, R. M., and ROCKET AF Investigators. (2011). Rivaroxaban versus warfarin in nonvalvular atrial fibrillation. N. Engl. J. Med. 365, 883-891.

PATS Collaborating Group. (1995). Post-stroke antihypertensive treatment study. Chin. Med. J. 108, 710-717.

Pengo, V., Cucchini, U., Denas, G., Davidson, B. L., Marzot, F., Jose, S. P., and Iliceto, S. (2010). Lower versus standard intensity oral anticoagulant therapy (OAT) in elderly warfarin-experienced patients with non-valvular atrial fibrillation. Thromb. Haemost. 103, 442-449.

Pfefferbaum, A., Mathalon, D. H., Sullivan, E. V., Rawles, J. M., Zipursky, R. B., and Lim, K. O. (1994). A quantitative magnetic resonance imaging study of changes in brain morphology from infancy to late adulthood. Arch. Neurol. 51, 874-887.

PROGRESS Collaborative Group. (2001). Randomised trial of a perindopril-based blood-pressurelowering regimen among 6105 individuals with previous stroke or transient ischaemic attack. Lancet 358, 1033-1041.

Prospective Studies Collaboration. (2007). Blood cholesterol and vascular mortality by age, sex, and blood pressure: a meta-analysis of individual data from 61 prospective studies with 55000 vascular deaths. Lancet 370, 1829-1839.

Rash, A., Downes, T., Portner, R., Yeo, W. W., Morgan, N., and Channer, K. S. (2007). A randomised controlled trial of warfarin versus aspirin for stroke prevention in octogenarians with atrial fibrillation (WASPO). Age Ageing 36, 151-156.

Rodgers, H., Greenaway, J., Davies, T., Wood, R., Steen, N., and Thomson, R. (2004). Risk factors for first-ever stroke in older people in the north East of England: A Population-Based Study. Stroke 35, 7-11.

Rojas, J. I., Zurrú, M. C., Romano, M., Patrucco, L., and Cristiano, E. (2007). Acute ischemic stroke and transient ischemic attack in the very old - risk factor profile and stroke subtype between patients older than 80 years and patients aged less than 80 years. Eur. J. Neurol. 14, 895-899.

Roob, G., Schmidt, R., Kapeller, P., Lechner, A., Hartung, H. P., and Fazekas F. (1999). MRI evidence of past cerebral microbleeds in a healthy elderly population. Neurology 52, 991-994.

Rosand, J., Hylek, E. M., O’Donnell, H. C., and Greenberg, S. M. (2000). Warfarin-associated hemorrhage and cerebral amyloid angiopathy: a genetic and pathologic study. Neurology 55, 947-951.

Schrader, J., Lüders, S., Kulschewski, A., Hammersen, F., Plate, K., Berger J., Zidek, W., Dominiak, P., Diener, H. C., and MOSES Study Group. (2005). Morbidity and mortality after stroke, eprosartan compared with nitrendipine for secondary prevention: principal results of a prospective randomized controlled study (MOSES). Stroke 36, 1218-1226.

Schwark, C., and Schellinge, P. D. (2006). Is old age really a reason to withhold thrombolytic therapy? J. Neurol. Neurosurg. Psychiatr. 77, 289.

Smith, E. E. (2010). Leukoaraiosis and stroke. Stroke 41, s139-s143.

Stroke prevention in atrial fibrillation III randomised clinical trial. Adjusted-dose warfarin versus lowintensity, fixed-dose warfarin plus aspirin for high-risk patients with atrial fibrillation. (1996). Lancet 348, 633-638.

Sylaja, P. N., Cote, R., Buchan, A. M., Hill, M., and Canadian Alteplase for Stroke Effectiveness Study Investigators. (2006). Thrombolysis in patients older than 80 years with acute ischaemic stroke: Canadian Alteplase for Stroke Effectiveness Study. J. Neurol. Neurosurg. Psychiatr. 77, 826-829.

Tanne, D., Gorman, M. J., Bates, V. E., Kasner, S. E., Scott, P., Verro, P. Binder, J. R., Dayno, J. M., Schultz, L. R., and Levine, S. R. (2000). Intravenous tissue plasminogen activator for acute ischemic stroke in patients aged 80 years and older: the tPA stroke survey experience. Stroke 31, 370-375.

The European Atrial Fibrillation Trial Study Group. (1995). Optimal oral anticoagulant therapy in patients with nonrheumatic atrial fibrillation and recent cerebral ischemia. $N$. Engl. J. Med. 333, 5-10.

The National Institute of Neurological Disorders, and Stroke rt-PA Stroke Study Group. (1995). Tissue plasminogen activator for acute 
ischemic stroke. N. Engl. J. Med. 333, 1581-1587.

The Stroke Prevention by Aggressive Reduction in Cholesterol Levels Investigators. (2006). High-dose atorvastatin after stroke or transient ischemic attack. N. Engl. J. Med. 355, 549-559.

van Walraven, C., Hart, R. G., Connelly, S., Austin, P. C., Mant, J., Hobbs, F. D., Koudstaal, P. J., Petersen, P., Perez-Gomez, F., Knottnerus, J. A., Boode, B., Ezekowitz, M. D., and Singer, D. E. (2009). Effect of age on stroke prevention therapy in patients with atrial fibrillation: the atrial fibrilation investigators. Stroke 40, 1410-1416.

Wahlgren, N., Ahmed, N., Davalos, A., Ford, G. A., Grond, M., Hacke, W., Hennerici, M. G., Kaste, M., Kuelkens, S., Larrue, V., Lees, K. R., Roine, R. O., Soinne, L., Toni,
D., Vanhooren, G., and SITS-MOST investigators. (2007). Thrombolysis with alteplase for acute ischaemic Stroke in the Safe Implementation of Thrombolysis in Stroke-Monitoring Study (SITSMOST): an observational study. Lancet 369, 275-282.

Warfarin versus aspirin for prevention of thromboembolism in atrial fibrillation: stroke prevention in atrial fibrillation II study. (1994). Lancet 343, 687-691.

Weverling-Rijnsburger, A. W., Jonkers, I. J., van Exel, E., Gussekloo, J., and Westendorp, R. G. (2003). Highdensity vs low-density lipoprotein cholesterol as risk factors for coronary artery disease and stroke in old age. Arch. Intern. Med. 163, 1549-1554.

Wolf, P. A., Abbott, R. D., and Kannel, W. B. (1991). Atrial fibrillation as an independent risk factor for stroke: the Framingham Study. Stroke 22, 983-988.

Wolf, P. A., D'Agostino, R. B., O'Neal, M. A., Sytkowski, P., Kase, C. S., Belanger, A. J., and Kannel, W. B. (1992). Secular trends in stroke incidence and mortality: the Framingham Study. Stroke 23, 1551-1555.

Yamaguchi, T. (2000). Optimal intensity of warfarin therapy for secondary prevention of stroke in patients with nonvalvular atrial fibrillation: a multicenter, prospective, randomized trial. Japanese Nonvalvular Atrial Fibrillation-Embolism Secondary Prevention Cooperative Study Group. Stroke 31, 817-821.

Conflict of Interest Statement: The author declares that the research was conducted in the absence of any commercial or financial relationships that could be construed as a potential conflict of interest.

Received: 27 September 2011; paper pending published: 08 November 2011; accepted: 13 December 2011; published online: 30 December 2011.

Citation: Fustinoni O (2011) The case for an elderly targeted stroke management. Front. Neur. 2:89. doi: 10.3389/fneur.2011.00089

This article was submitted to Frontiers in Stroke, a specialty of Frontiers in Neurology.

Copyright (๑ 2011 Fustinoni. This is an open-access article distributed under the terms of the Creative Commons Attribution Non Commercial License, which permits non-commercial use, distribution and reproduction in other forums, provided the original authors and source are credited. 